\title{
Information Search Strategies
}

\section{Abstract}

After completing this learning unit, you will be able to:

- Identify types of catalogues;

- Differentiate sources of information;

- Argue the need for cataloging.

\section{Keywords}

Library catalogues $\cdot$ Information sources $\cdot$ Classification

\subsection{Traditional Library Catalogues}

- Represent lists of name, concepts or objects, recorded on different information carriers, arranged according to certain classification schemes and serving information purposes (Fig. 6.1);

- Offer information concerning the contents of an information centre:

- Works of a certain author; and

- Works referring to a certain subject

\section{Types of catalogues:}

- Alphabetical catalogue on authors' names and titles: groups bibliographical descriptions of primary and secondary works in general alphabetical order of authors' names and of titles for works with more than three authors;

- Systematic catalogue: groups bibliographical descriptions of primary and secondary works according to a systematic classification scheme. 


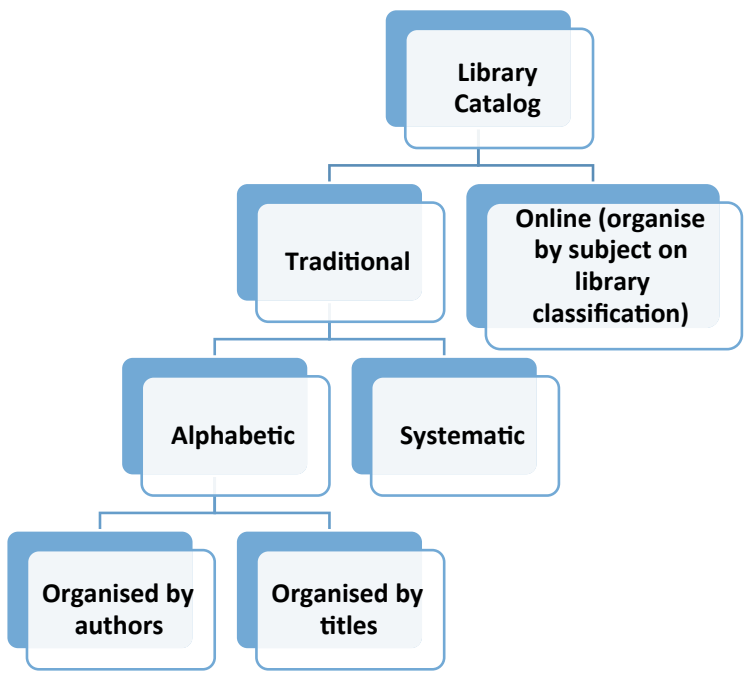

Fig. 6.1 Library catalogues classification

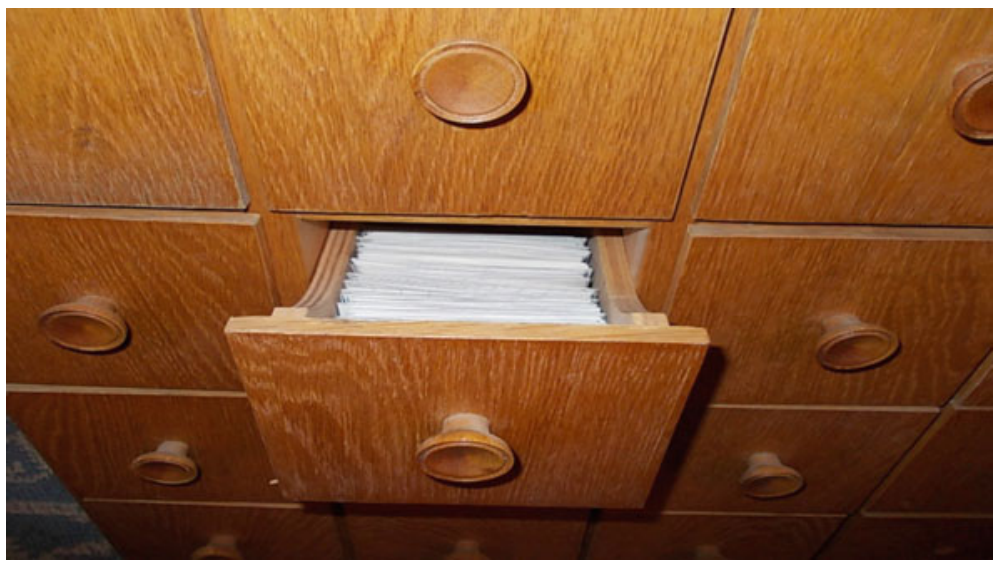

Fig. 6.2 Traditional card catalogue

Traditional catalogues are catalogues of cards with bibliographical descriptions (Fig. 6.2).

Cases of information sources in a traditional catalogue:

Case A: user knows author, but does not know the title of the desired work

- Uses alphabetic catalogue of authors' names;

- Looks within the catalogue until he finds the desired author;

- Writes down the location identification details; and

- Goes to the identified location to find the desired work. 
Case B: user knows the domain of the desired publication, but does not know the author

- Uses the systematic catalogue, where UDC class identifies the searched domain;

- Looks within the respective file until he identifies the desired publication;

- Writes down the source identification details; and

- Goes to the identified location to find the desired work.

\section{Example of research in traditional library}

Research theme: forestry.

\section{Understanding the concept}

- Search in dictionaries or encyclopedias with definition term forestry.

\section{Establishing keywords}

Definitions of forestry generate several keywords including:

- Forestry;

- Forest cultivation;

- Forest arrangement;

- Forest exploitation;

- Forest protection; and

- Forest.

\section{Identification of information sources}

In traditional alphabetic and systematic catalogues, there are two types of information sources:

- Printed:

- Atlases;

- Dictionaries;

- Encyclopedias;

- Books;

- Brochures; and

- Journals.

- Non-printed:

- Audio/video records; and

- Databases (collections of information stored to be accessed by computer). 
Case A: user knows the author, but does not know the title of the desired work

- Uses alphabetic catalogue of the file, according to author's names;

- Looks within the respective file until he identifies the desired author;

- Writes down the identification details for location on the library shelf; and

- Goes to the identified location and finds the desired work;

- User looks for a work written by Iosif Leahu, but does not know the title;

- Looks in alphabetic catalogue for letter L;

- Within the letter L records, he browses the cards until he identifies the required author: Leahu;

- Writes down the identification details for location on the library shelf; and

- Goes to the identified location to find the desired information, namely the book Amenajarea Pădurilor.

\section{Case B: user knows the work domain but does not know the author}

- Uses the systematic catalogue, where at the appropriate class he will find the desired domain;

- Looks within the respective file until he identifies the required work;

- Writes down the identification details for location on the library shelf; and

- Goes to the identified location and finds the desired information.

User looks for a publication in the Forestry domain, namely Amenajarea pădurilor, but does not know its author:

- Looks in the systematic catalogue (on human knowledge domains) where at class 63 he will find the desired domain, respectively Forestry;

- Looks through the respective file until he identifies the required work: Amenajarea pădurilor;

- Writes down the identification details for location on the library shelf; and

- Goes to the identified source to find the desired information.

\subsubsection{Search Information on Internet}

Search Engines for Academic Use:

Search engines are maintained by computer programs, with minimal human intervention. Search engines search a wider range of web sites than directories, but there are fewer quality-control mechanisms (Libguides.utoledo.edu. 2019).

- Google-includes a directory and access to Usenet;

- Google Scholar-focuses or retrieving scholarly literature and academic resources; 
- Lycos;

- 360 Daily (video searching);

- RefSeek-Academic Search Engine; and

- Yahoo! Search.

\subsubsection{MetaSearch Tools}

Metasearch tools search the other search tools ... one-stop-searching the web.

- Dogpile; and

- Ixquick.

\section{More information about search tools and how they work:}

- Search Engine Show-Down-information on search engine features, technical analyses, search strategies, reviews, and more; and

- Search Engine Watch-information for web searchers and web designers about how search engines work (Libguides.utoledo.edu. 2019).

Libguides.utoledo.edu. (2019). LibGuides: The Internet and the World Wide Web: Home. [online] Available at: https://libguides.utoledo.edu/internet [Accessed 5 Feb. 2019].

Google search tips: (Libguides.mit.edu. 2019).

- Searches are not case sensitive.

- Keywords may be entered in lower or upper case or a combination of both. Exception: Boolean operator OR

\section{- Word order matters.}

- Google ranks the first word slightly higher than the second, the second slightly more than the third, etc.

- Google ignores most punctuation and symbols. Exceptions:

- Dollar sign when used to indicate price;

- Underscore or hyphen when used to connect words; and

- Symbols when used to convey meaning such as a programming language (C ++ ), and musical terms (G\#) (Libguides.mit.edu. 2019). 


\section{- Google uses automatic word stemming.}

- Google does not allow wildcards to be used for variable ends of words.

Instead, Google searches for all possible word variations (Libguides.mit.edu. 2019).

\section{Suggested Teaching}

\section{Warm-up}

Every course begins with a short organisational time. In this activity, greet the students, invite them to the classroom, find out the number of absences, possibly the reasons they could not reach the class. Following this step, to capture of attention, you can use a game in order to thaw the atmosphere, to facilitate a dynamic group which will be beneficial to the next activity.

Share paper sheets to the participants. Ask students to recall a game familiar from their childhood. Then, they will each write his own name on his note and two true things about his own person and a false one. The teacher will collect all the notes and read them out loud, and the participants will guess which are the true and false claims. Group members have the opportunity to discover how well they know each other and amuse at the same time.

\section{Review of previous knowledge}

Concepts such as: document types, information cataloguing elements, indexing, classification, thesaurus will be briefly defined and described. The outstanding questions from the previous lesson will be answered and/or suggestions will be made to find the answers. Homework will be checked, clarifying incorrect aspects, if any, or other student queries.

\section{Teaching activities}

The starting point of this lesson can be the first application in the previous chapter, namely: Discover the cataloging system for public and university libraries. Write down what this system is and what the main features are.

If building an application was the homework, checking it will be a good introductory time. If not, students will be asked to access the sites of named institutions to discover information about the cataloging systems.

Students will be asked what are the reasons for making catalogues. They will also be asked to name a few of the advantages of cataloging. An operational definition of the library catalogue will be built. The schema Library catalogues classification will be explained and types of existing catalogues. It is recommended 
that the schema is already printed and placed in a visible place for the whole group to see. If this is not possible, it can be constructed by drawing on the whiteboard or a flip chart, in conjunction with the explanations given.

In the next activity of the lesson, participants will be divided into two subgroups. Each of the two subgroups has precise and complementary tasks. One group will take over case A, which was shared in the summary that relates to this chapter, while the second group will have as a task case B. Members will be encouraged to cooperate and to share roles in order to solve the tasks quickly and effectively. At the end of the activity, both groups will be congratulated for their involvement and manner of solving the task.

After completing the tasks, participants will receive a new task, which they will do individually. The teacher will prepare, prior to the commencement of the course, a number of cards, which will have an approximate equal number, depending on the number of participants in the group. On half of them the teacher will write the letter $\mathrm{A}$, and on the other half he will write the letter B. These letters will correspond to the two cases from the summary described above.

The teacher will ask each participant to choose a card from the box prepared and he will explain that the two letters correspond to the two previously demonstrated situations. Each participant will have total freedom in choosing the subject of research and alone will follow the approach that was demonstrated within the team.

\section{Review}

Students will reform into the two groups formed at the beginning of the course. Each group will create a mind-map, on A3 paper sheets, with the most important elements, concepts discussed during the course. Participants will have a maximum of five minutes for this activity. As we have emphasised in previous activities, this part of the course has the role of imprinting on the students' minds essential concepts, facilitating the learning of the concepts from the lesson.

\section{Applications}

Find research that comes under your sphere of interest or an author or multiple authors who have written relevant papers in your research project area. Try searching for information about them.

Find the most cited articles in your studied field. Also, rank the work of the author you are looking for, depending on the number of citations it has. 


\section{Evaluation}

1. Which of information sources listed below are printed? Mark the correct answers.

- Atlases;

- Databases;

- Encyclopedias;

- Audio records;

- Dictionaries;

- $\quad$ Video records;

- Brochures.

2. Define traditional library catalogues.

3. How are online catalogues organised?

4. Define an alphabetical catalogue.

\section{Webography}

AASL, AECT. (1998). Information literacy standards for student learning: standards and indicators. Chicago: ALA. Retrieved October 10, 2011, from http://www.ala.org/ala/mgrps/ divs/aasl/aaslarchive/pubsarchive/informationpower/InformationLiteracyStandards_final.pdf.

ACRL, Association of College and Research Libraries. (2000). Information literacy competency standards for higher education. Retrieved November 12, 2011, from http://www.ala.org/ala/ mgrps/divs/acrl/standards/informationliteracycompetency.cfm.

Biblioteca Națională a României. (2012). Limbajul de indexare LIVES-RO. Retrieved January 6, 2012, from http://www.bibnat.ro/dyn-doc/ghid-lives/limbajlivesro.pdf.

IFLA. (2002). Guidelines on information literacy for lifelong learning. International Federation of Library Association. Retrieved December 12, 2011, from http://www.ifla.org/VII/s42/pub/ILGuidelines2006.pdf.

Information literacy standards for higher education: A manifesto/third meeting on information competencies. (2002). http://www.infolitglobal.info/media/UNESCO_IL_state_of_the_art_ report_-_Draft070803.doc. 
Lau, J. (2004). International guidelines on information literacy. Retrieved November 4, 2011, from http://bivir.uacj.mx/dhi/DoctosNacioInter/Docs/Guidelines.pdf.

Libguides.mit.edu. (2019). LibGuides: Google search tips: Getting started. Retrieved February 5, 2019, from https://libguides.mit.edu/google.

Libguides.utoledo.edu. (2019). LibGuides: The internet and the world wide web: Home. Retrieved February 5, 2019, from https://libguides.utoledo.edu/internet.

Presidential Committee on Information Literacy. (1989). Final Report. Chicago. Retrieved September 22, 2011, from http://www.ala.org/ala/mgrps/divs/acrl/publications/whitepapers/ presidential.cfm.

\section{Bibliographic Recommendations}

How Do I Use Library Catalogue (OPAC) To Find Books in the Library? - Libanswers. (2019). Libanswers.Lib.Xjtlu.Edu.Cn. Retrieved February 15, 2019, from http://libanswers.lib.xjtlu. edu.cn/faq/1.

Research Guides: Finding Books In The Library Catalogue: Home. (2019). Guides.Lib.Uwo.Ca. Retrieved February 15, 2019, from https://guides.lib.uwo.ca/books.

The Library. (2019). Library guides: How do I find books? Finding your book in the library. Guides.Lib.Uchicago.Edu. Retrieved February 15, 2019, from http://guides.lib.uchicago.edu/c. $\mathrm{php} ? \mathrm{~g}=297325 \& \mathrm{p}=1984695$.

Open Access This chapter is licensed under the terms of the Creative Commons Attribution 4.0 International License (http://creativecommons.org/licenses/by/4.0/), which permits use, sharing, adaptation, distribution and reproduction in any medium or format, as long as you give appropriate credit to the original author(s) and the source, provide a link to the Creative Commons license and indicate if changes were made.

The images or other third party material in this chapter are included in the chapter's Creative Commons license, unless indicated otherwise in a credit line to the material. If material is not included in the chapter's Creative Commons license and your intended use is not permitted by statutory regulation or exceeds the permitted use, you will need to obtain permission directly from the copyright holder.

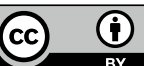

